DOI: 10.46340/eujem.2020.6.5.6

Liliia Granat

ORCID ID: https://orcid.org/0000-0002-8203-4647

Kyiv National University of Trade and Economics, Ukraine

\title{
BRAND ORIENTED MARKETING MANAGEMENT OF ONLINE TRADE ENTERPRISES
}

\author{
Лілія Гранат \\ Київський національний торговельно-економічний університет, Україна

\section{БРЕНД-ОРІСНТОВАНЕ УПРАВЛІННЯ МАРКЕТИНГОМ ПІДПРИЕМСТВ ОНЛАЙН-ТОРГІВЛІ}

In the conditions of e-commerce rapid spread and development, the issue of online trade enterprise management becomes relevant. At the same time, the aspect of brand-oriented management is important, which significance is illustrated in this article. To determine the success factors of the Internet project in the field of brand management, marketing research was conducted. Based on its results presented in this paper, a summary table of brand-oriented factors for marketing management at e-commerce enterprises is proposed. It reflects the views of business and consumers. The list of factors has been transformed into a system of brand-oriented marketing management functions. Performing these functions, the e-commerce company claims to build and develop a strong brand in the future.

Keywords: brand management, company brand management, marketing management, online store, online store marketing.

Постановка проблеми. На сьогоднішній день ми спостерігаємо стрімкий на глобальному рівні розвиток мережі Інтернет. Тенденція не оминає і Україну - майже 94\% користуються Інтернетом, a 6 із 10 українців являються регулярними користувачами мережі ${ }^{1}$.

Всесвітньою тенденцією також є поширення електронної торгівлі. Сума онлайн-продажів по світу та прогнози на найближче майбутнє вражають. Згідно інформації, наведеній статистичним порталом Statista, у 2019 р. онлайн продажі склали 3,5 трлн. дол. США, а у 2021 р. очікується продажів на 4,9 трлн.дол. США, що, для порівняння, перевищує річний ВВП Франції (2,8 трлн. дол.. США у 2018 p. $\left.^{2}\right)^{3}$

Незважаючи на низький рівень технічної готовності та незначну частку в загальній сумі оптовороздрібної торгівлі України (8\%), наша держава також щорічно демонструє збільшення обсягів продажів онлайн. У 2018 р. показник сягає 2,42 млрд. євро.

Така ситуація актуалізує питання управління інтернет-проектами, зокрема інтернет-магазинами та ПРЕТ - підприємствами, що частково або повністю ведуть свою діяльність, тобто електронну торгівлю, за допомогою інтернет-магазина.

Аналіз публікацій. Існує багато літератури з управління маркетингом традиційних підприємств торгівлі (наприклад, роботи Ф. Котлера ${ }^{5}$, Д. Гілберта ${ }^{6}$, Ж.-Ж.Лабена ${ }^{7}$, Л. Балабанова

\footnotetext{
${ }^{1}$ Internet World Stats (2020). Internet Growth Statistics. Today's road to e-Commerce and Global Trade Internet Technology Reports $<$ http://www.internetworldstats.com/emarketing.htm> (2020, вересень, 15).

${ }^{2}$ World Bank (2020). GDP (current US\$) <https://data.worldbank.org/indicator/NY.GDP.MKTP.CD> (2020, вересень, 15).

${ }^{3}$ Clement, J. (2020). Retail e-commerce sales worldwide from 2014 to 2023(in billion U.S. dollars). Statista <https://www.statista.com/statistics/379046/worldwide-retail-e-commerce-sales> (2020, вересень, 15).

4 Златьева, Д. (2019). Семимильними кроками: підсумки українського е-соmmerce і логістики за 2018. RAU <https://rau.ua/novyni/itogi-e-commerce-2018/> (2020, вересень, 15).

${ }^{5}$ Котлер, Ф., Армстронг, Г., Сондерс, Дж., Вонг, В. (1999). Основы маркетинга. Київ: Вильямс.

${ }^{6}$ Гилберт, Д. (2005). Управление розничным маркетингом. Москва: ИНФРА-М, XVI, 571.

7 Ламбен, Ж.-Ж. (1996). Стратегический маркетинг. Европейская перспектива. Санкт-Петербург: Наука.

${ }^{8}$ Балабанова, Л. В. (2012). Маркетинг підприємства. Київ: ЦУЛ.
} 
та багато інших) та створенню інтернет-магазинів від таких авторів, як, наприклад, Апопій В. ${ }^{1}$, Кравець B. ${ }^{2}$, Фоміна O. ${ }^{3}$. Проте ще не достатньо досліджена тема саме управління інтернетпроектами, їх ведення. Аналогічно і стосовно бренд-менеджменту - розроблена теорія управління товарними брендами в рамках підприємства, брендами офлайн-компаній, персоналій та інших об'єктів. Нам відомі роботи таких дослідників як Т. Гед ${ }^{4}$, Ромат . $^{5}$, Зозульов О. ${ }^{6}$, Приходченко Я. ${ }^{7}$ та ін. Але тема управління брендами інтернет-магазинів досі розкрита не достатньо.

Постановка завдання. Встановити, яким має бути управління підприємствами роздрібної електронної торгівлі. Визначити роль брендингових технологій в ньому. Скласти список факторів $\mathrm{i}$ функцій, реалізація яких забезпечує ефективне та комплексне бренд-орієнтоване управління ПРЕТ.

Виклад основного матеріалу. Огляд лідерів світового онлайн-ринку та українських брендів, представлених онлайн, показує, що бренди мають вагоме значення для інтернет-компаній. Окрім загальних для будь-якого середовища переваг (збільшення акціонерної вартості компанії, інвестиційна привабливість, можливість встановлення преміальних цін, створення бар'єрів для виходу на ринок нових конкурентів, захист підприємства у процесі роботи з партнерами, забезпечення стійкого попиту на продукцію продавця, вплив на репутацію, стресостійкість компанії у порівнянні з «безіменними» пропозиціями, лояльність до підприємства, переваги при виході на нові географічні ринки, переваги при диверсифікації та диференціації), варто відзначити те, що бренди підприємств електронної роздрібної торгівлі більш глобальні, можуть контактувати зі своєю аудиторією на будь-якій відстані, у будь-який час та у зручний для користувача спосіб, надаючи більше інформації. Контактувати із брендом онлайн набагато легше i дешевше, емоційна прихильність та лояльність формуються швидше. Бренди в мережі Інтернет більш динамічні та цікаві, інноваційні, передові, менш старомодні, нудні і традиційні. Варто зазначити також наступні факти:

- кращі онлайн-магазини світу являються одними з найдорожчих брендів планети, що свідчить про перспективність електронної комерції та високе значення бренду в існуванні інтернетпроекта ${ }^{8}[16]$

- бренди українських інтернет-магазинів також являються одними із найдорожчих брендів України, що відповідає ситуації у світі, незважаючи на разючу різницю у вартостях ${ }^{9}$;

- серед найбільших інтернет-магазинів світу $\epsilon$ мультибрендові і такі, що реалізують продукцію єдиного бренда - що підкреслює можливість застосування обох стратегій та значимість бренда при будь-якому сценарії розвитку компанії ${ }^{10}$.

При цьому не можна стверджувати, що бренд є виключною причиною становлення та успіху інтернет-проекту. За даними досліджень різних компаній, а також на основі власних проведених дисертаційних досліджень, можна сказати, що успіх ПРЕТ залежить від комплексу факторів, урахування яких дозволяє побудувати сильний бренд та розвивати його. Тобто ми вважаємо, що управління ПРЕТ повинно бути комплексним і бренд-орієнтованим.

3 метою визначення чинників, які дозволяють ПРЕТ бути обраними їхніми клієнтами та сприйматися як бренди, було проведено опитування представників інтернет-торгівлі та онлайнпокупців (опитування проводилося шляхом анкетування представників 140 ПРЕТ та 400 онлайнпокупців). Результати цих досліджень дали змогу виділити групу факторів, врахування яких при управлінні маркетингом ПРЕТ забезпечить їм можливість стати брендами. Під цими факторами маємо на увазі все, що так чи інакше здійснює вплив на становлення та сприйняття бренда ПРЕТ.

\footnotetext{
${ }_{1}^{1}$ Апопій, В. В. (2003). Інтернет-торгівля: проблеми і перспективи розвитку. Регіональна економіка, 1, 25.

${ }^{2}$ Кравець, В. М. (2004). Інтернет-комерція в Україні. Вісник НБУ, $3,9$.

${ }^{3}$ Фомина, О. (2016). Как открыть интернет-магазин с нуля. Москва: РИПОЛ Классик.

${ }^{4}$ Гэд, Т. (2016). 4D брэндинг. Взламывая корпоративный код сетевой экономики; Стокгольмская школа экономики в Санкт-Петербурге. Москва.

${ }^{5}$ Ромат, Є. В., Чикусова, М. Ю. (2018). Бренд-менеджмент. Київ: КНТЕУ.

6 Зозульов, О., Нестерова, Ю. (2008). Бренд як нематеріальний актив у постіндустріальному суспільстві. Економіка України, 3, 4-11.

${ }^{7}$ Приходченко, Я. В. (2009). Бренд-менеджмент торговельних підприємств в умовах маркетингової орієнтації: автореферат дисертація на здобуття наукового ступеня кандидата економічних наук. Донецьк: Донецький національний університет економіки і торгівлі імені Михайла Туган-Барановського.

${ }^{8}$ Interbrand (2020). Homepage <https://www.interbrand.com/> (2020, вересень, 15).

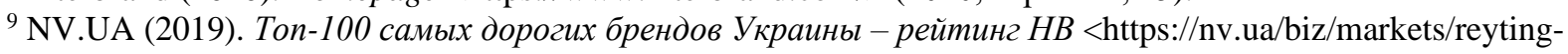
ukrainskih-brendov-top-100-samyh-dorogih-torgovyh-marok-ukrainy-novosti-ukrainy-50055102.html> (2020, вересень, 15); E-Awards (2020). Blank-2 <https://www.e-awards.com.ua/blank-2> (2020, вересень, 15). ${ }^{10}$ Interbrand (2020). Homepage <https://www.interbrand.com/> (2020, вересень, 15).
} 
Важливо відмітити, погляди представників бізнесу та клієнтів стосовно вагомості тих чи інших факторів відрізняються - це також проілюстровано результатами проведених досліджень. Тобто можна виокремити два принципово різні підходи - фактори, що є важливими з точки зору бізнесу, та фактори, що є важливими з точки зору клієнтів. Вони не є взаємовиключними. Проте ступінь значення окремих з них може бути суб єктивно не дооцінено однією зі сторін.

3 точки зору покупців, рішення про купівлю в мережі Інтернет, а не офлайн, зумовлюється базовими чи функціональними критеріями вибору місця та способу покупки (можливість порівняння товарів, широкий асортимент, доступність географічно віддалених товарів, ціна та інші). Аналогічно і при виборі конкретного ПРЕТ вагоміше значення мають цінові фактори (2,48 балів із 3), товарні $(2,26)$, збутові $(1,82)$, технологічні $(1,58)$, сервісні $(1,42)$. Саме це говорить про наявність «брендового» потенціалу та вільних ніш у свідомості цільової аудиторії підприємств роздрібної електронної торгівлі. При цьому, покупці також враховують репутаційні фактори $(1,88)$, фактори лояльності $(1,47)$ комунікаційні (хоча і меншість - 1,21). Дані оцінки, а також наступні факти, встановлені з проведених досліджень, дають змогу робити висновок про невід'ємну роль брендів в успішності ПРЕТ:

- $26 \%$ користувачів спочатку заходять на сайт конкретного ПРЕТ і починають товарний пошук на ньому;

- обізнаність про сайт та формування стійкої асоціації бренда 3 певними товарними категоріями відіграє вирішальну роль при виборі інтернет-магазина для чверті покупців;

- 70\% опитуваних генерують прямий трафік на окремі магазини (заходять на сайт шляхом введення адреси чи його назви);

- понад $2 / 3$ респондентів відповіли, що скоріше звернуть увагу на вже знайомі для них інтернет-магазини;

- брендові запити демонструють значно вищі показники переходів, ніж не брендові.

Отже, ПРЕТ повинно працювати над базовими маркетинговими елементами, щоб задовольняти попит клієнтів. В той же час критично важливо як для покупців, так і для представників бізнесу, створювати при цьому додаткові цінності - такі, що можуть забезпечити бренди. 3-поміж іншого основного, відповідно точки зору онлайн-покупців, потрібно не забувати про наступне: категоріям;

- проводити маркетингові дослідження по вивченню пошукових запитів по власним товарним цінами;

- представляти широкий якісний асортимент (в рамках категорії по брендам) за адекватними

- максимально доступно та вичерпно подавати інформацію про товари на сайті;

- представляти можливість порівняння товарів та комфортної оплати;

- здійснювати сео-оптимізацію сайтів на предмети пошуку;

- використовувати платну контекстну рекламу з рекламними зверненнями, релевантними пошуковим запитам;

- формувати обізнаність про ПРЕТ;

- працювати з лояльністю покупців;

- працювати з репутацією ПРЕТ.

Представники онлайн-торгівлі України дещо по-іншому оцінюють фактори вибору ПРЕТ покупцями. В цілому, їх пріоритети також можна назвати більш прагматичними та раціональними, ніж емоціональними - про які не слід забувати для побудови бренда. Окрім розбіжностей в ранжуванні факторів, вартим уваги $є$ певна переоцінка їх зі сторони бізнесу у порівнянні з думкою споживачів. Це може відображати відповідальне ставлення бізнесу до своєї роботи. Незважаючи на високу оцінку базових факторів (цінові, товарні, збутові), деякі з показників свідчать про часткове нерозуміння цільової аудиторії та надання вищого значення тактичним діям перед стратегічними (наприклад, вища оцінка значення дизайну ніж юзабіліті сайту, чи можливості взяти участь в акції перед наявністю товару).

Дослідження демонструють, що представники ПРЕТ нижче оцінюють значення бренда інтернет-магазина, ніж покупці. При цьому вище оцінюють значення бренда товару. Отже, вони покладаються на побудову власного бренда за рахунок представлених у ньому товарів або взагалі не мають на меті побудову бренда власного ПРЕТ.

Через відсутність різного типу ресурсів та складність процесу ПРЕТ приділяють недостатню увагу маркетинговим дослідженням - звідси нерозуміння цільової аудиторії та недооцінка стратегічно важливих моментів. Також лише 61\% ПРЕТ здійснюють сегментацію, незважаючи на технічні можливості, що надають їх сайти. 
Ще гірша ситуація із позиціонуванням - більшість підприємств роздрібної електронної торгівлі не застосовують дану маркетингову технологію. При цьому бачимо нереалізований потенціал в плані перших кроків на шляху до побудови бренда, оскільки більшість із ПРЕТ можуть назвати власні конкурентні переваги.

Лише одиниці мають схематичне відображення власного бренда, що пояснюється браком досвіду та ресурсів. Аналогічно з моделями управління брендом - даний інструмент практично не використовується на українських ПРЕТ.

Говорячи безпосередньо про бренд ПРЕТ: представники української електронної комерції реалізують лише окремі елементи, що можуть бути частинами бренда, тобто немає комплексного підходу. Вони також здебільшого не проводять маркетингових досліджень на предмет оцінки ефективності бренда.

Перешкодою на шляху до збільшення кількості брендів в українському Інтернеті є також ситуація з реалізацією комунікацій: здебільшого вони не пов'язані між собою, не відповідають бренду, не становлять інтегровану систему.

3 боку представників ПРЕТ продемонстрований рівень бренд-менеджменту пояснюється проблемами з ресурсами, що є в їх розпорядженні, реалізацією стратегічного управління та окремих маркетингових елементів. 3 урахуванням того, як саме виконуються функції ПРЕТ (згідно з результатами проведеного дослідження), робимо висновок про те, що українським представникам електронної комерції бракує комплексності, стратегічності та послідовності для побудови сильних брендів і використання переваг, що ними надаються. В цілому, підхід до маркетингу ПРЕТ на даний момент можна назвати не бренд-орієнтованим.

Ми співставили усі зазначені побажання та вимоги з обох сторін і склали зведену таблицю бренд-орієнтованих факторів управління маркетингом ПРЕТ (таблиця 1).

3 метою реалізації бренд-орієнтованого управління маркетингом ПРЕТ ми пропонуємо трансформацію наведених факторів в систему бренд-орієнтованих функцій управління маркетинговою діяльністю ПРЕТ, що представлені у таблиці 2. Виконуючи всі вказані функції, підприємство роздрібної електронної торгівлі претендує на побудову та подальший розвиток сильного бренда. Передбачаємо можливість різного ранжування функцій в рамках даного набору відповідно загальної стратегії компанії, іiї маркетингової стратегії та позиціонування.

На нашу думку, як і на підприємствах роздрібної торгівлі, так і в діяльності ПРЕТ, виконання кожної функції має проходити певний систематичний і циклічний процес, запропонований далі:

1 етап - аналіз фактичної ситуації на основі маркетингових досліджень,

2 етап - постановка цілей,

3 етап - аналіз поточних умов та наявних ресурсів, планування дій по досягненню цілей, визначення критеріїв досягнення цілей,

4 етап - моніторинг виконання та оцінка результатів.

Реалізація даного процесу в межах виконання кожної окремої функції забезпечує здійснення загальних функцій менеджменту, таких як планування, інформаційне забезпечення, організація, контроль. Відповідно, маємо комплекс специфічних бренд-орієнтованих функцій управління маркетингом ПРЕТ, що не суперечать базовим основам менеджменту (рис.1.).

В залежності від функції кожен із етапів запропонованого процесу управління вимагатиме окремого комплексу дій, критеріїв, показників і метрик оцінки ефективності. Дотримання схеми процесу бренд-менеджменту та якість виконання його функцій характеризують загальний рівень ефективності бренд-менеджменту ПРЕТ.

Висновок. В умовах сьогодення стратегічно важливо займатися побудовою та розвитком бренда підприємства, що частково або повністю веде свою торгову діяльність в мережі Інтернет. Дослідження представників галузі та іiі клієнтів дали змогу визначити фактори, що впливають на становлення бренда ПРЕТ. Ми трансформували дані фактори у систему бренд-орієнтованих функцій управління маркетинговою діяльністю ПРЕТ. Виконання запропонованих функцій, на нашу думку, $є$ втіленням бренд-менеджменту для підприємств роздрібної електронної торгівлі. Воно надає можливості створення та розвитку сильного бренда компанії. Відповідно до цього, ми надаємо перевагу функціональному підходу оцінки ефективності бренд-орієнтовної діяльності ПРЕТ. Розробка рекомендацій щодо оцінки такої ефективності, побудова моделі управління брендорієнтованої діяльності ПРЕТ можуть стати продовженням розвитку даної теми. 


\section{Бренд-орієнтовані фактори управління маркетингом ПРЕТ}

\begin{tabular}{|c|c|c|c|c|}
\hline № & Група факторів & $\begin{array}{c}\text { Фактори, значення яких } \\
\text { визнають представники } \\
\text { бізнесу }\end{array}$ & $\begin{array}{l}\text { Фактори, значення яких визнають } \\
\text { споживачі та представники бізнесу }\end{array}$ & $\begin{array}{c}\text { Фактори, значення яких } \\
\text { визнають покупці }\end{array}$ \\
\hline \multirow[t]{4}{*}{1} & \multirow[t]{4}{*}{$\begin{array}{l}\text { Стратегічного } \\
\text { управління }\end{array}$} & $\begin{array}{l}\text { маркетингове } \\
\text { середовище }\end{array}$ & & \\
\hline & & сегментація & & \\
\hline & & позиціонування & & \\
\hline & & моделювання & & \\
\hline \multirow[t]{4}{*}{2} & \multirow{4}{*}{$\begin{array}{l}\text { Товарні } \\
\text { фактори }\end{array}$} & & якість товару & наявність товару \\
\hline & & & Асортимент & $\begin{array}{l}\text { країна-виробник } \\
\text { товару }\end{array}$ \\
\hline & & & $\begin{array}{c}\text { портфель брендів в рамках } \\
\text { асортименту }\end{array}$ & \\
\hline & & & Упаковка & \\
\hline \multirow[t]{3}{*}{3} & \multirow[t]{3}{*}{ Цінові } & & ціна на товари & \\
\hline & & & $\begin{array}{c}\text { цінові заходи стимулювання } \\
\text { збуту }\end{array}$ & \\
\hline & & & умови оплати & \\
\hline \multirow[t]{3}{*}{4} & \multirow[t]{3}{*}{ Збутові фактори } & & $\begin{array}{c}\text { наявність офлайн- } \\
\text { представництва }\end{array}$ & \\
\hline & & & представленість товару & \\
\hline & & & способи отримання товару & \\
\hline 5 & Технологічні & & юзабіліті сайту & \\
\hline \multirow[t]{2}{*}{6} & \multirow[t]{2}{*}{ Сервісні } & & $\begin{array}{l}\text { наявність онлайн- } \\
\text { консультантів }\end{array}$ & $\begin{array}{c}\text { швидкість } \\
\text { обслуговування }\end{array}$ \\
\hline & & & наявність додаткових послуг & $\begin{array}{c}\text { гарантійне } \\
\text { обслуговування }\end{array}$ \\
\hline \multirow[t]{4}{*}{7} & \multirow[t]{4}{*}{ Комунікаційні } & $\begin{array}{c}\text { комунікаційна } \\
\text { політика }\end{array}$ & $\begin{array}{c}\text { представленість контактної } \\
\text { інформації }\end{array}$ & \\
\hline & & $\begin{array}{c}\text { позиція сайту } \\
\text { у пошуковій мережі }\end{array}$ & відомість інтернет-магазину & \\
\hline & & & ідентичний стиль бренда & \\
\hline & & & заходи стимулювання збуту & \\
\hline 8 & Лояльності & CRM-система & програми лояльності & $\begin{array}{c}\text { власний попередній } \\
\text { досвід покупок } \\
\text { в інтернет-магазині }\end{array}$ \\
\hline \multirow[t]{3}{*}{9} & \multirow[t]{3}{*}{ Репутації } & & відгуки про інтернет-магазин & $\begin{array}{c}\text { безпека персональних } \\
\text { даних }\end{array}$ \\
\hline & & & $\begin{array}{c}\text { рейтинг інтернет-магазину } \\
\text { на сайтах-агрегаторах }\end{array}$ & \\
\hline & & & рекомендації знайомих & \\
\hline \multirow[t]{4}{*}{10} & \multirow[t]{4}{*}{ Ресурсні } & $\begin{array}{c}\text { інформаційні (про } \\
\text { ринок, споживачів, } \\
\text { конкурентів) }\end{array}$ & & \\
\hline & & фінансові & & \\
\hline & & трудові & & \\
\hline & & матеріально-технічні & & \\
\hline
\end{tabular}

Джерело: розроблено автором 
Таблиця 2

\section{Система бренд-оріснтованих функцій управління маркетинговою діяльністю ПРЕТ}

\begin{tabular}{|c|c|c|c|c|c|}
\hline № & 䍃商 & Фактори & & 蛋意 & Деталізація функцій \\
\hline \multirow[t]{4}{*}{1} & \multirow{4}{*}{ 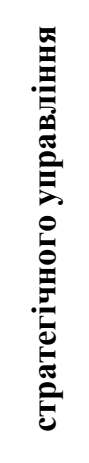 } & $\begin{array}{l}\text { маркетингове } \\
\text { середовище }\end{array}$ & & \multirow{4}{*}{ 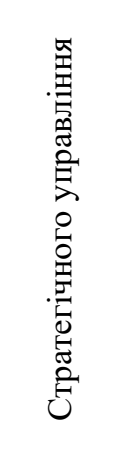 } & \multirow{4}{*}{$\begin{array}{l}\text { - проведення маркетингових досліджень щодо ситуації } \\
\text { на ринку, споживачів, конкурентів, контактних груп } \\
\text { • сегментація ринку } \\
\text { • розробка стратегії позиціонування } \\
\text { - застосування моделі управління брендом } \\
\text { - побудова та використання моделі бренда } \\
\text { - розробка комплексної стратегії та маркетингового } \\
\text { плану по їі реалізації } \\
\text { • реєстрація ТМ } \\
\text { - реєстрація доменного імені в зоні UA або } \\
\text { міжнародних зонах }\end{array}$} \\
\hline & & сегментація & & & \\
\hline & & позиціонування & & & \\
\hline & & моделювання & & & \\
\hline \multirow[t]{4}{*}{2} & \multirow{4}{*}{ 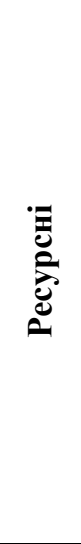 } & $\begin{array}{c}\text { інформаційні (про } \\
\text { ринок, споживачів, } \\
\text { конкурентів) }\end{array}$ & & \multirow{4}{*}{ 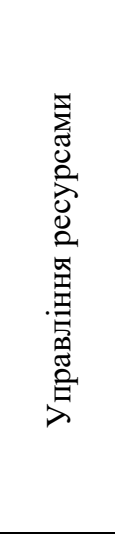 } & \multirow{4}{*}{$\begin{array}{l}\text { - управління організаційною структурою } \\
\text { маркетингового відділу } \\
\text { • внутрішній маркетинг } \\
\text { • налагодження тристоронньої системи обміну } \\
\text { інформацією між відділом маркетингу, іншими } \\
\text { відділами підприємства та ринком } \\
\text { • контроль використання фінансових ресурсів, а саме - } \\
\text { рівня рентабельності та ефективності витрат на бренд- } \\
\text { менеджмент } \\
\text { • участь у забезпеченні необхідних для реалізації } \\
\text { брендингу та бренд-менеджменту матеріально- } \\
\text { технічних засобів } \\
\text { • робота з партнерами }\end{array}$} \\
\hline & & фінансові & & & \\
\hline & & трудові & & & \\
\hline & & матеріально-технічні & & & \\
\hline \multirow[t]{6}{*}{3} & \multirow{6}{*}{ } & якість товару & \multirow{6}{*}{$\gamma$} & \multirow{6}{*}{ 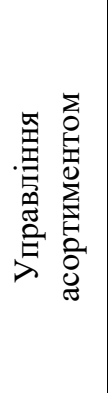 } & \multirow{6}{*}{$\begin{array}{l}\text { Управління асортиментом ПРЕТ згідно позиціонування } \\
\text { бренда: } \\
\text { • релевантна потребам ЦА широта/ } \\
\text { глибина/гармонійність асортименту з урахуванням } \\
\text { необхідного рівня якості усіх складових продукту } \\
\text { • управління портфелем брендів в рамках асортименту } \\
\text { • забезпечення необхідного рівня наявності товарного } \\
\text { асортименту для виконання замовлень } \\
\text { • управління упаковкою товарного асортименту }\end{array}$} \\
\hline & & асортимент & & & \\
\hline & & наявність товару & & & \\
\hline & & країна-виробник товару & & & \\
\hline & & упаковка & & & \\
\hline & & $\begin{array}{c}\text { портфель брендів } \\
\text { в рамках асортименту }\end{array}$ & & & \\
\hline \multirow[t]{3}{*}{4} & \multirow[b]{3}{*}{ 商 } & ціна на товари & & \multirow{3}{*}{ 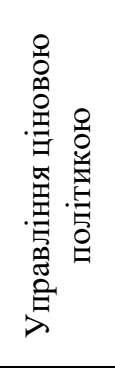 } & \multirow{3}{*}{$\begin{array}{l}\text { Управління ціновою політикою ПРЕТ згідно } \\
\text { позиціонування бренда: } \\
\text { • визначення цінового рівня } \\
\text { • визначення заходів та меж цінового стимулювання } \\
\text { збуту } \\
\text { • забезпечення комфортних та безпечних } \\
\text { взаємовигідних умов здійснення оплати } \\
\text { • аналіз ефективності заходів цінового стимулювання } \\
\text { збуту }\end{array}$} \\
\hline & & $\begin{array}{c}\text { цінові заходи } \\
\text { стимулювання збуту }\end{array}$ & & & \\
\hline & & умови оплати & & & \\
\hline \multirow[t]{3}{*}{5} & \multirow{3}{*}{ 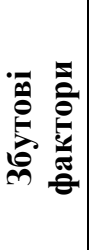 } & $\begin{array}{c}\text { наявність офлайн- } \\
\text { представництва }\end{array}$ & & \multirow{3}{*}{ 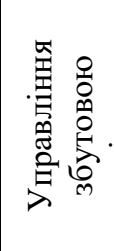 } & \multirow{3}{*}{$\begin{array}{l}\text { Участь у прийнятті рішення щодо збутової політики: } \\
\text { • про необхідність офлайн представництва } \\
\text { • про мерчандайзинг в інтернет-магазині та офлайн } \\
\text { представництві (за наявності), } \\
\text { • про процес виконання замовлень та передачу товару }\end{array}$} \\
\hline & & представленість товару & & & \\
\hline & & $\begin{array}{c}\text { способи отримання } \\
\text { товару }\end{array}$ & & & \\
\hline
\end{tabular}


Продовження табл. 2

\begin{tabular}{|c|c|c|c|c|}
\hline № & 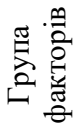 & Фактори & 焉星 & Деталізація функцій \\
\hline \multirow[t]{2}{*}{6} & \multirow[b]{2}{*}{ 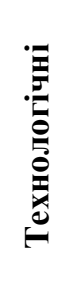 } & юзабіліті сайту & \multirow[b]{2}{*}{ 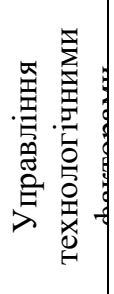 } & \multirow{2}{*}{$\begin{array}{l}\text { Участь у створенні зручного для користування, } \\
\text { надійного та відповідного до бренду інтернет- } \\
\text { магазину: } \\
\text { • розробка рекомендацій щодо покращення юзабіліті } \\
\text { на основі досліджень поведінки користувачів сайту та } \\
\text { глобальних тенденцій } \\
\text { • реалізація інновацій }\end{array}$} \\
\hline & & інновації & & \\
\hline \multirow[t]{4}{*}{7} & \multirow{4}{*}{ ن } & $\begin{array}{l}\text { наявність онлайн- } \\
\text { консультантів }\end{array}$ & \multirow{4}{*}{ 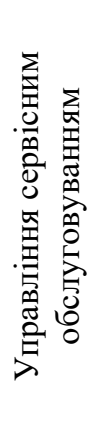 } & \multirow{4}{*}{$\begin{array}{l}\text { Робота над забезпеченням відповідного } \\
\text { позиціонуванню та запитам клієнтів рівня сервісу: } \\
\text { • впровадження сервісного обслуговування } \\
\text { • організаційна робота по налагодженню процесу } \\
\text { обслуговування } \\
\text { • контроль рівня обслуговування }\end{array}$} \\
\hline & & $\begin{array}{c}\text { наявність додаткових } \\
\text { послуг (порівняння } \\
\text { товарів) }\end{array}$ & & \\
\hline & & $\begin{array}{c}\text { швидкість } \\
\text { обслуговування }\end{array}$ & & \\
\hline & & $\begin{array}{c}\text { гарантійне } \\
\text { обслуговування }\end{array}$ & & \\
\hline \multirow[t]{6}{*}{8} & \multirow{6}{*}{ 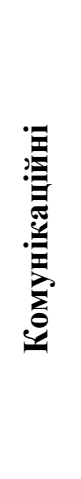 } & комунікаційна політика & \multirow{6}{*}{ 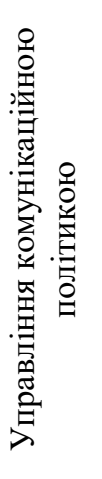 } & \multirow{6}{*}{$\begin{array}{l}\text { Формування і підтримка обізнаності та лояльності } \\
\text { до бренда і його об`єкту, в рамках чого: } \\
\text { • формування комунікаційної політики } \\
\text { • планування стратегії присутності } \\
\text { - вибір ІСМК } \\
\text { - вибір інструментів просування } \\
\text { - розробка та реалізація комунікації } \\
\text { - аналіз ефективності комунікації } \\
\text { - стимулювання збуту }\end{array}$} \\
\hline & & $\begin{array}{c}\text { позиція сайту } \\
\text { у пошуковій мережі }\end{array}$ & & \\
\hline & & $\begin{array}{c}\text { представленість } \\
\text { контактної інформації }\end{array}$ & & \\
\hline & & $\begin{array}{c}\text { відомість інтернет- } \\
\text { магазину }\end{array}$ & & \\
\hline & & ідентичність бренда & & \\
\hline & & стимулювання збуту & & \\
\hline \multirow[t]{3}{*}{9} & \multirow{3}{*}{ 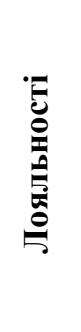 } & програми лояльності & \multirow{3}{*}{ 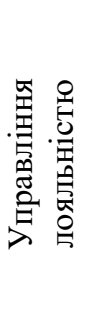 } & \multirow{3}{*}{$\begin{array}{l}\text { Управління лояльністю клієнтів: } \\
\text { - аналіз інформації про клієнтів з метою управління їх } \\
\text { поведінкою } \\
\text { - розробка та впровадження релевантних програм } \\
\text { лояльності } 3 \text { метою подовження життєвого циклу } \\
\text { клієнтів } \\
\text { - розробка та впровадження окремих заходів та акцій } \\
\text { зі стимулювання лояльності }\end{array}$} \\
\hline & & $\begin{array}{c}\text { попередній досвід } \\
\text { покупок в } \\
\text { інтернет-магазині }\end{array}$ & & \\
\hline & & CRM-програми & & \\
\hline \multirow[t]{4}{*}{10} & \multirow{4}{*}{ : } & $\begin{array}{c}\text { відгуки про інтернет- } \\
\text { магазин }\end{array}$ & \multirow{4}{*}{ 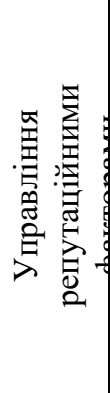 } & \multirow{4}{*}{$\begin{array}{l}\text { Управління репутаційними факторами: } \\
\text { - стимулювання позитивного зворотного зв’язку } \\
\text { - робота із негативом } \\
\text { - реалізація рекомендаційних програм } \\
\text { - захист персональних даних клієнтів та працівників } \\
\text { - реалізація PR }\end{array}$} \\
\hline & & $\begin{array}{c}\text { рейтинг інтернет- } \\
\text { магазину на сайтах- } \\
\text { агрегаторах }\end{array}$ & & \\
\hline & & рекомендації знайомих & & \\
\hline & & $\begin{array}{c}\text { безпека персональних } \\
\text { даних }\end{array}$ & & \\
\hline
\end{tabular}

Джерело: розроблено автором 


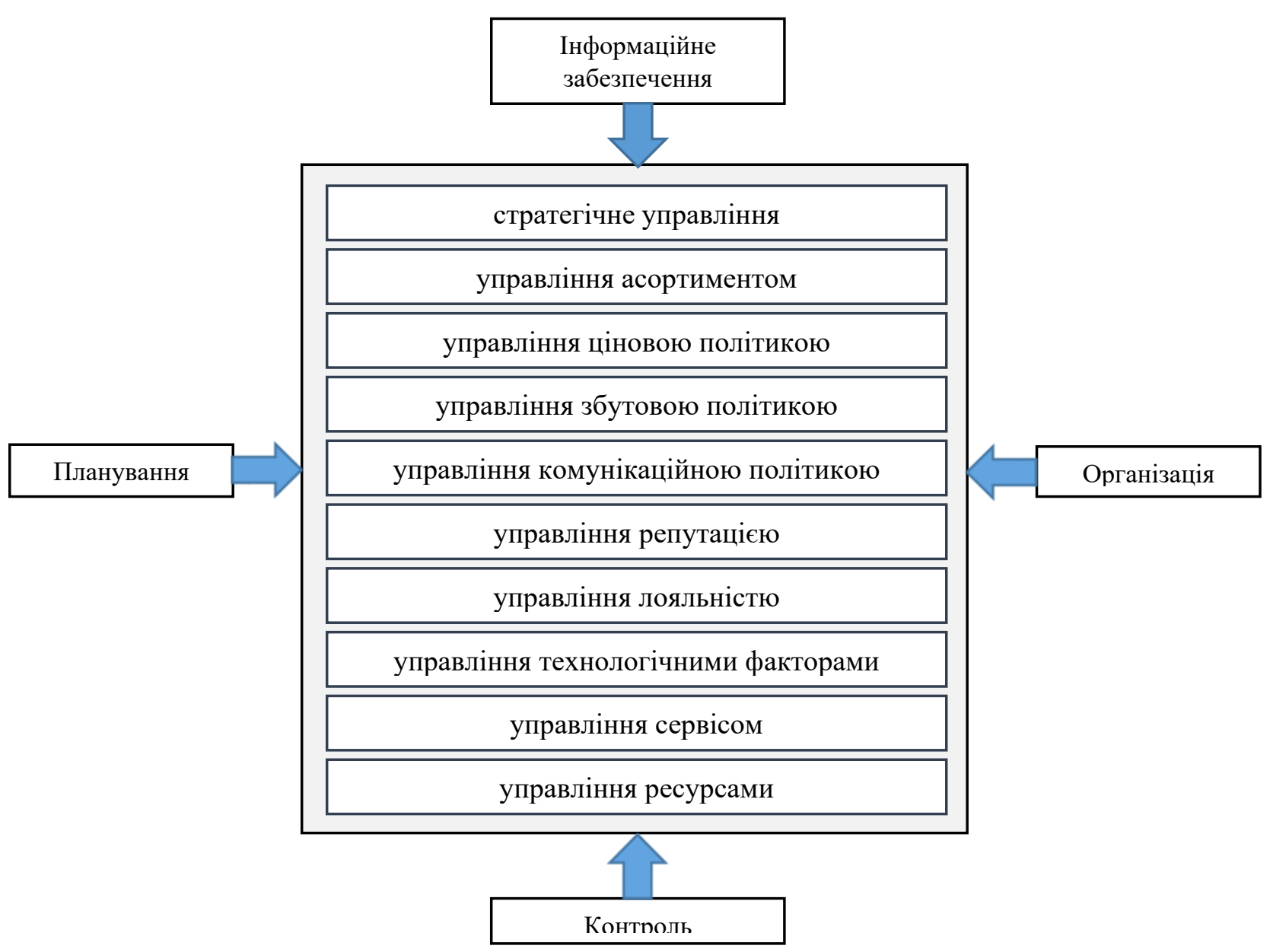

\section{Рис. 1. Система бренд-оріснтованих функцій управління маркетинговою діяльністю ПРЕТ}

\section{References:}

1. Internet World Stats (2020). Internet Growth Statistics. Today's road to e-Commerce and Global Trade Internet Technology Reports <http://www.internetworldstats.com/emarketing.htm> (2020, September, 15). [in English].

2. World Bank (2020). GDP (current US\$) <https://data.worldbank.org/indicator/NY.GDP.MKTP.CD> (2020, September, 15). [in English].

3. Clement, J. (2020). Retail e-commerce sales worldwide from 2014 to 2023 (in billion U.S. dollars). Statista <https://www.statista.com/statistics/379046/worldwide-retail-e-commerce-sales> (2020, September, 15). [in English].

4. Zlatieva, D. (2019). Semymylnymy krokamy: pidsumky ukrayinskoho e-commerce i lohistyky za 2018 [Seven steps: the results of Ukrainian e-commerce and logistics for 2018]. $R A U<$ https://rau.ua/novyni/itogi-e-commerce-2018/> (2020, September, 15). [in Ukrainian].

5. Kotler, F., Armstrong, G., Sonders, Dzh., Vong, V. (1999). Osnovy marketinga [Marketing Basics]. Kyiv: Williams. [in Ukrainian].

6. Gilbert, D. (2005). Upravleniye roznichnym marketingom [Retail Marketing Management]. Moscow: INFRA-M, $X V I, 571$. [in Russian].

7. Lamben, J.-J. (1996). Strategicheskiy marketing. Yevropeyskaya perspektiva [Strategic marketing. European perspective]. St. Petersburg: Nauka. [in Russian].

8. Balabanova, L. V. (2012). Marketynh pidpryyemstva [Enterprise marketing]. Kyiv: CUL. [in Russian].

9. Apopiy, V. V. (2003). Internet-torhivlya: problemy i perspektyvy rozvytku [Internet commerce: problems and prospects of development]. Rehionalna ekonomika [Regional economy], 1, 25. [in Ukrainian].

10. Kravets, V. M. (2004). Internet-komertsiya v Ukrayini [Internet commerce in Ukraine]. Visnyk NBU [Bulletin of the NBU], 3, 9. [in Ukrainian].

11. Fomina, O. (2016). Kak otkryt internet-magazin s nulya [How to open an online store from scratch]. Moscow: RIPOL Classic. [in Russian]. 
12. Ged, T. (2016). 4D brending. Vzlamyvaya korporativnyy kod setevoy ekonomiki; Stokgolmskaya shkola ekonomiki v Sankt-Peterburge [4D branding. Hacking the corporate code of the network economy; Stockholm School of Economics in St. Petersburg]. Moscow. [in Russian].

13. Romat, Ye. V., Chykusova, M. Yu. (2018). Brend-menedzhment [Brand management]. Kyiv: KNTEU. [in Ukrainian].

14. Zozulov, O., Nesterova, Yu. (2008). Brend yak nematerialnyy aktyv u postindustrialnomu suspilstvi [Brand as an intangible asset in a post-industrial society]. Ekonomika Ukrayiny [Ukraine economy], 3, 4-11. [in Ukrainian].

15. Prykhodchenko, Ya. V. (2009). Brend-menedzhment torhovelnykh pidpryyemstv v umovakh marketynhovoyi oriyentatsiyi [Brand management of trade enterprises in terms of marketing orientation]: avtoreferat dysertatsiya na zdobuttya naukovoho stupenya kandydata ekonomichnykh nauk [abstract dissertation for the degree of candidate of economic sciences]. Donetsk: Mykhailo Tuhan-Baranovsky Donetsk National University of Economics and Trade. [in Ukrainian].

16. Interbrand (2020). Homepage <https://www.interbrand.com/> (2020, September, 15). [in English].

17. NV.UA (2019). Top-100 samykh dorogikh brendov Ukrainy - reyting $N V$ [Top-100 most expensive brands in Ukraine - NV rating] <https://nv.ua/biz/markets/reyting-ukrainskih-brendov-top-100-samyh-dorogih-torgovyhmarok-ukrainy-novosti-ukrainy-50055102.html> (2020, September, 15). [in Russian].

18. E-Awards (2020). Blank-2 <https://www.e-awards.com.ua/blank-2> (2020, September, 15). [in English]. 